Article

\title{
Beeswax by-Products Efficiently Counteract the Oxidative Damage Induced by an Oxidant Agent in Human Dermal Fibroblasts
}

\author{
Francesca Giampieri ${ }^{1,+}{ }^{\oplus}$, Massimiliano Gasparrini ${ }^{1,+}{ }^{\mathbb{C}}$, Tamara Y. Forbes-Hernández ${ }^{1}{ }^{\mathbb{C}}$, \\ Piera Pia Manna ${ }^{1}$, Jiaojiao Zhang ${ }^{1}$, Patricia Reboredo-Rodríguez ${ }^{1,2}$, Danila Cianciosi ${ }^{1}$, \\ Jose L. Quiles ${ }^{3}{ }^{1}$, Cristina Torres Fernández-Piñar ${ }^{4}$, Francisco Josè Orantes-Bermejo ${ }^{4}$, \\ Stefano Bompadre ${ }^{5}$, Sadia Afrin ${ }^{1, * \mathbb{D}}$ and Maurizio Battino ${ }^{1, * \mathbb{D}}$ \\ 1 Dipartimento di Scienze Cliniche Specialistiche ed Odontostomatologiche (DISCO)-Sez. Biochimica, \\ Facoltà di Medicina, Università Politecnica delle Marche, 60131 Ancona, Italy; f.giampieri@univpm.it (F.G.); \\ m.gasparrini@univpm.it (M.G.); tamara.forbe@gmail.com (T.Y.F.-H.); p.piera@hotmail.it (P.P.M.); \\ zh.jojo@yahoo.com (J.Z.); preboredo@uvigo.es (P.R.-R.); danila.cianciosi@gmail.com (D.C.) \\ 2 Departamento de Química Analítica y Alimentaria, Grupo de Nutrición y Bromatología, \\ Universidade de Vigo, 32004 Ourense, Spain \\ 3 Department of Physiology, Institute of Nutrition and Food Technology “José Mataix", Biomedical Research \\ Center, University of Granada, Avda del Conocimiento sn., Armilla, 18100 Granada, Spain; jlquiles@ugr.es \\ 4 Apinevada Analytical Laboratory of Bee Products, Barrancos s/n, Lanjarón, 18420 Granada, Spain; \\ calidad@apinevada.com (C.T.F.-P.); director@apinevada.com (F.J.O.-B.) \\ 5 Dipartimento di Scienze Biomediche e Sanità Pubblica, Università Politecnica delle Marche, \\ 60131 Ancona, Italy; s.bompadre@univpm.it \\ * Correspondence: dolla.bihs@gmail.com (S.A.); m.a.battino@univpm.it (M.B.); \\ Tel.: +39-071-220-4646 (F.G. \& M.B.) \\ + These authors have contributed equally to this work.
}

Received: 26 August 2018; Accepted: 18 September 2018; Published: 19 September 2018

\begin{abstract}
The antioxidant capacity and the phytochemical composition of two by-products from beeswax recycling processes were recently investigated. The aim of the present work was to evaluate the efficacy of one of these by-products, MUD1, against the oxidative stress induced by 2,2'-azobis(2-amidinopropane) dihydrochloride (AAPH) in human dermal fibroblast (HDF) cells. After a preliminary viability assay, the protective effect of MUD1 was investigated through the measurement of apoptosis level, the reactive oxygen species (ROS) and nitrite $\left(\mathrm{NO}_{2}{ }^{-}\right)$production, the level of protein and lipid biomarkers (carbonyl groups, total glutathione and thiobarbituric acid-reactive substance) of oxidative damage, and the measurement of antioxidant enzymes activities (glutatione peroxidase, glutathione reductase, glutathione transferase, superoxide dismutase and catalase). The obtained results showed that MUD1 exerted protective effects on HDF, increasing cell viability and counteracted the oxidative stress promoted by AAPH-treatment, and improved mitochondria functionality and wound healing capacities. This work shows the antioxidant effects exerted by beeswax by-products, demonstrating for the first time their potential against oxidative stress in human dermal fibroblast cells; however, further research will be necessary to evaluate their potentiality for human health by more deeply in vitro and in vivo studies.
\end{abstract}

Keywords: honey; beeswax; ROS; oxidative stress; prevention; antioxidant effects; human dermal fibroblasts 


\section{Introduction}

The reduction of the energy and water consumption, and in a residual way, the recovery of energy from waste represent the actual main goal of the food industry [1]. For this reason, investment in research, new production systems and recovery technologies for the recycle of food waste biocomponents, are becoming an urgent need [1]. The development of these strategies can lead to numerous advantages, such as the valorization of bioactive molecules that could be used in the food chain or for medicinal purposes. Some examples are represented by collagen derived from fish (e.g., skin, bones, and fins), seaweed or plants [1]. In this context, the products derived from honey production such as beeswax, propolis, pollen, venom and royal jelly are attracting attention of the scientific community, due to their interesting nutritional composition [2,3], which could have a potential impact on biomedicine. In particular, beeswax and its derivatives have been recognized for their antibacterial properties and traditionally used for the treatment of wounds, burns, psoriasis, and topic dermatitis [4]. According to the European food safety authority, beeswax is accepted for its safety and can also be used as a glossing, flavoring, preserving or supplementing agents for food [5]. It is estimated that approximately $30 \mathrm{~kg}$ of honey yielded $1 \mathrm{~kg}$ of wax, so the use of the latter could have a significant economic impact [3]. In addition, a recent study from our group highlighted the proximal, nutritional, and phenolic content as well as the antioxidant capacity of two beeswax recycling by-products (MUD1 and MUD2). We also demonstrated their anticarcinogenic effects in human hepatocellular carcinoma (HepG2) cells [2]. Both derivatives-although to a greater extent MUD1-induced cytotoxic effects in this cell line by reducing cell viability, increasing reactive oxygen species (ROS) generation, and deteriorating mitochondrial functionality, thanks to the phytochemical contents [2].

Oxidative stress represents the main cause of most common chronic diseases including inflammation, cardiovascular diseases, diabetes, metabolic syndrome, and cancer [6]; in recent years, numerous studies have demonstrated that dietary antioxidants from plant foods represent an efficient strategy to counteract this condition, and can be considered a useful tool for the maintenance of human health status and well-being conditions [7-10]. On the experience of our previous reports [7-10] and the antioxidant potential of MUD1 (it presents $1435.66 \pm 71.78 \mathrm{mg} / 100 \mathrm{~g}$ and $295.84 \pm 14.80 \mathrm{mg} / 100 \mathrm{~g}$ of Total phenolic content and total flavonoids content, respectively) [2], in the present study we evaluated the efficacy of beeswax by-products, MUD1, as a potential therapeutic agent against oxidative damage induced by 2,2'-aszobis(2-amidinopropane) dihydrochloride (AAPH) in Human Dermal Fibroblasts (HDF). HDF are considered an excellent model system to study several aspects of cell physiology, and are widely used to evaluate the in vitro effect of substances of interest in the prevention of oxidative damage caused by different agents $[8,11]$. We hypothesized that if beeswax byproducts, such as the potent antioxidant MUD1, could protect HDF cells from oxidative damage induced by AAPH, they could be considered as potential therapeutic agents used to speed up wound healing in patients suffering from chronic diseases. To quantify the direct protective effects of MUD1 against ROS damage by AAPH on HDF cells, we measured the cell viability, apoptosis rate, $\mathrm{ROS}$ and $\mathrm{NO}_{2}{ }^{-}$levels, and the biomarkers of oxidative damage to biomolecules (i.e., proteins and lipids). Moreover, to assess the indirect effects of MUD1 protecting against ROS damage by AAPH on HDF cells, we measured the activity antioxidant enzymes, the mitochondria functionality, and the wound healing capabilities. To the best of our knowledge this is the first study that investigates the protective effect of beeswax by-products on AAPH-induced damage in the HDF cell line.

\section{Results and Discussion}

\subsection{MUD1 Treatments Reduced AAPH-Mediated ROS Production and $\mathrm{NO}_{2}{ }^{-}$Accumulation}

According to our recently published results that showed that MUD1 contains high content in fiber, protein, carbohydrate, polyphenol and flavonoid, and presents antioxidant properties [2], we decided to test the efficacy of MUD1 against AAPH-induced stress in HDF cells. The measurement 
of intracellular ROS production represents a very useful tool for the evaluation of oxidative stress promoted by AAPH [11,12]. The accumulation of ROS can result in the hyperactivation of the inflammatory response, tissue damage, and oxidative stress phenomena [13]. In the present work, the protective effect of MUD1 on AAPH-induced ROS production was highlighted when applied at $250 \mu \mathrm{g} / \mathrm{mL}$ and $750 \mu \mathrm{g} / \mathrm{mL}$ (Figure 1). In HDF cells, MUD1 treatment reduced ROS production compared to the control group. In cells pre-treated with MUD1 and stressed with AAPH, this reduction became significant $(p<0.05)$ at all MUD1 applied concentrations. Nitric oxide $(N O)$ is widely considered an important regulatory and effector molecule with different biological functions and it represents a fundamental component involved in many physiological and pathophysiological processes [13,14]. As reported in Figure 1, MUD1 was able to reduce the level of NO derivative nitrite production compared to untreated cells $(p<0.05)$. AAPH-treatment significantly increased $\mathrm{NO}_{2}{ }^{-}$accumulation $(p<0.05)$, which was efficiently counteracted by MUD1 pre-treatment, restoring also in this case, levels similar to a control group at $750 \mu \mathrm{g} / \mathrm{mL}$. Similar effects were obtained when Manuka honey was used as a therapeutic agent against AAPH induced oxidative stress in HDF cells by reducing intracellular ROS production and $\mathrm{NO}_{2}{ }^{-}$accumulation [11]. Also, pre-treatment with strawberry extracts have been demonstrated to counteract the oxidative damage induced by different chemical and biological agents such as hydrogen peroxide [15], ultraviolet radiations [16], and lipopolysaccharide $[7,8]$.

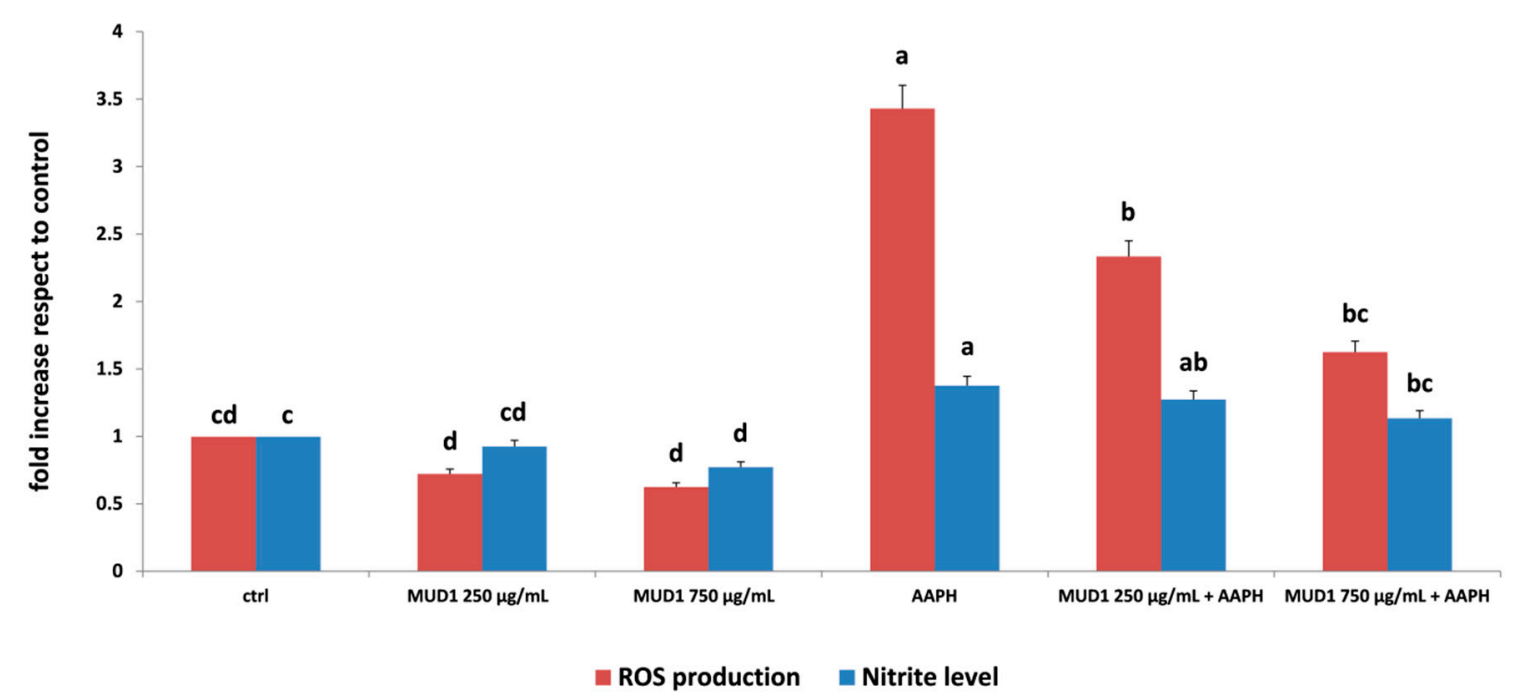

Figure 1. Reactive oxygen species (ROS) production (red bars) and $\mathrm{NO}_{2}{ }^{-}$level (blue bars) in human dermal fibroblast (HDF) cells treated with different concentrations of MUD1 (250-750 $\mu \mathrm{g} / \mathrm{mL})$ for $24 \mathrm{~h}$, AAPH $(10 \mathrm{mM})$ for $24 \mathrm{~h}$ and with different concentrations of MUD1 and then with AAPH. Data are expressed as mean values $\pm \mathrm{SD}$. Columns belonging to the same set of data with different superscript letters are significantly different $(p<0.05)$.

\subsection{Regulation of Apoptosis Level by MUD1}

The augment of ROS production could be related to the induction of apoptosis, a process that leads to many biochemical and morphological modifications, such as cell shrinkage, nucleosomal degradation, chromatin condensation, and the activation of caspases [17]. Our results demonstrated that MUD1 treatment improved HDF viability, increasing the number of live cells and lowering the amount of dead cells at all concentrations applied especially in the presence of APPH (Figure 2). At the same time, AAPH treatment significantly increased the number of apoptotic cells $(p<0.05)$, while MUD1 extracts significantly $(p<0.05)$ reduced this amount at the both concentrations applied. At $750 \mu \mathrm{g} / \mathrm{mL}$ the quantified apoptosis rate was comparable to the untreated group either when applied alone than when applied before incubation with AAPH (Figure 2). These results are similar with those 
reported for Manuka honey that in HDF significantly $(p<0.05)$ reduced the AAPH induced apoptosis rate for neutralizing the oxidative damage [11].

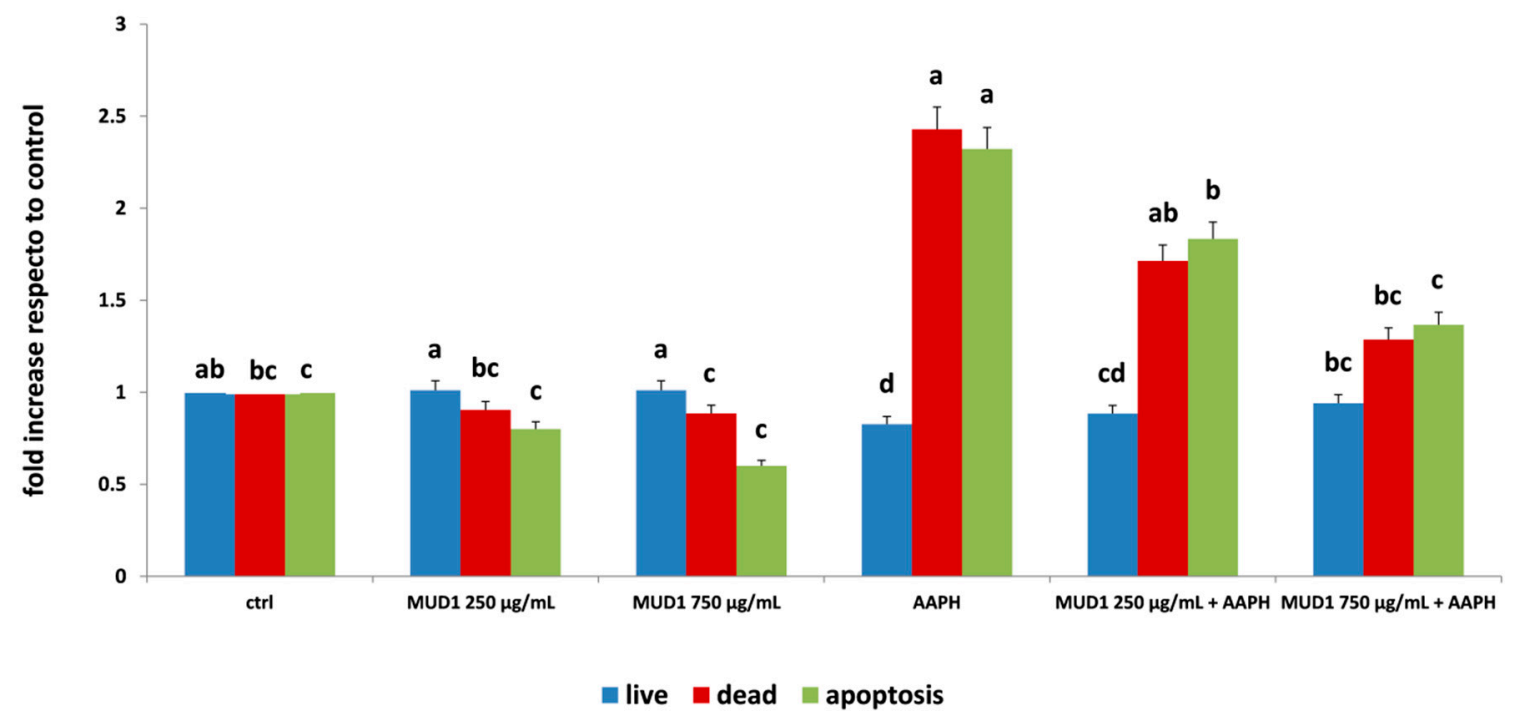

Figure 2. Live (blue bars), dead (red bars), and apoptosis (green bars) levels in HDF cells treated with different concentrations of MUD1 (250-750 $\mathrm{g} / \mathrm{mL})$ for $24 \mathrm{~h}$, AAPH $(10 \mathrm{mM})$ for $24 \mathrm{~h}$ and with different concentrations of MUD1 and then with AAPH. Data are expressed as mean values $\pm \mathrm{SD}$. Columns belonging to the same set of data with different superscript letters are significantly different $(p<0.05)$.

\subsection{MUD1 Treatment Reduced Protein and Lipid Biomarkers of Oxidative Stress}

In order to quantify the oxidative damage in the HDF cells after treatment with AAPH and/or MUD1, lipid peroxidation and protein carbonyl formation, common markers of lipid and protein oxidation, respectively, were evaluated. Lipid peroxidation is a free radical-mediated chain reaction, which can be stopped through enzymatic means or by free radical scavenging by antioxidants [18]. Some diagnostic tests are available for quantification of the end-products of lipid peroxidation, being the thiobarbituric acid-reactive substance (TBARS) assay the most commonly used. Meanwhile, the production of carbonyl groups represents an early event in oxidative stress, and can be efficiently used to measure the accumulation of protein oxidative damage [19]. In addition to lipid peroxidation and protein carbonyl formation, total glutathione (GSH) level is another important marker of oxidation, since it plays an important role in maintaining the normal reduced state of cells and strongly counteracts the harmful effects of oxidative stress and detoxifying xenobiotics [20].

As reported in Figure 3, MUD1 treatments reduced protein carbonyl content and increased GSH levels compared to untreated cells, while HDF subjected to AAPH treatment showed a remarkable protein damage $(p<0.05)$. Pre-treatment with MUD1 improved the levels of AAPH-induced protein damage, obtaining values similar to the control groups with MUD1 at $750 \mu \mathrm{g} / \mathrm{mL}$ and $250 \mu \mathrm{g} / \mathrm{mL}$, for GSH and protein carbonyl content, respectively. Similar results were obtained in case of lipid oxidation (Figure 3): MUD1 extract significantly lowered TBARS level in respect to the control group $(p<0.05)$, exerting positive effects also before the oxidative stress induced by AAPH, in when applied at $250 \mu \mathrm{g} / \mathrm{mL}$ and $750 \mu \mathrm{g} / \mathrm{mL}(p<0.05)$. Our findings are in agreement with previous studies reporting the capacity of different natural bioactive compounds or food extract in increasing the levels of GSH in different stressed models $[7,8,14,18]$. 


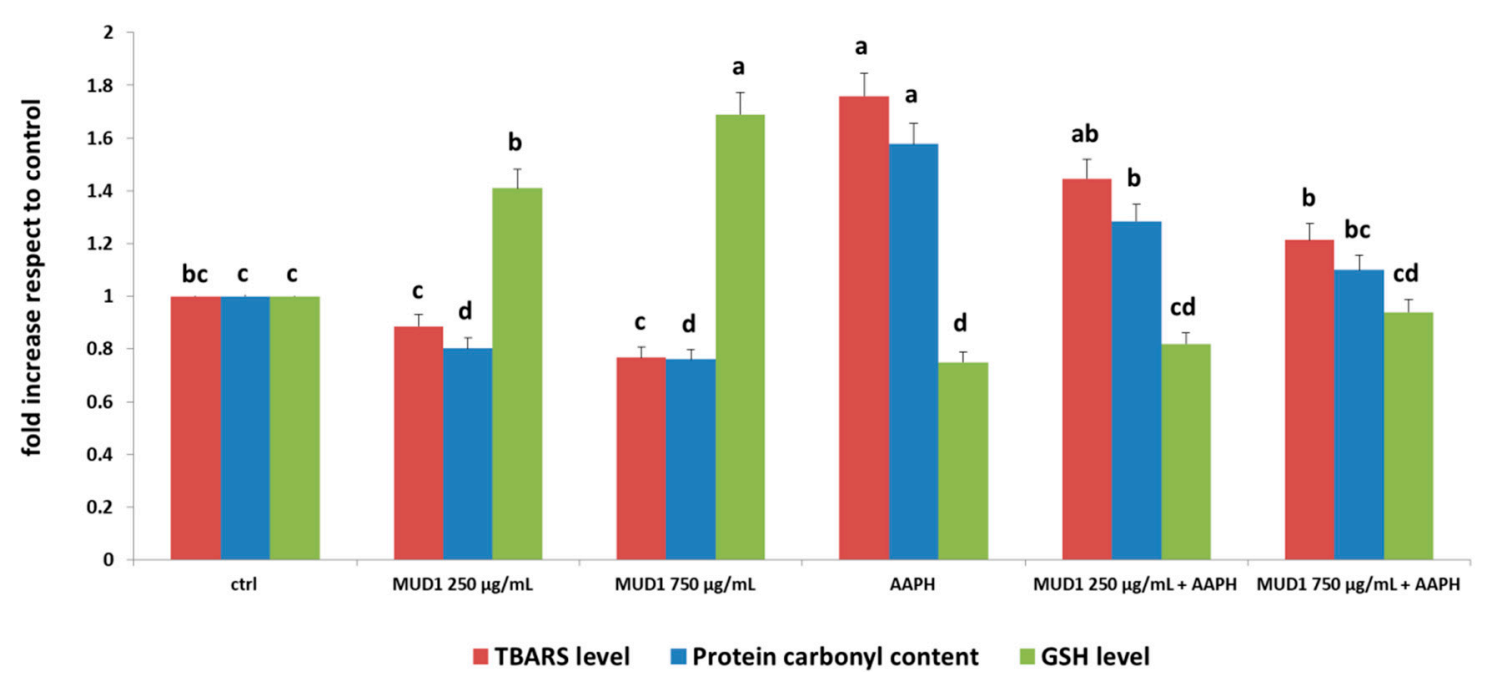

Figure 3. TBARS level (red bars), Protein carbonyl content (blue bars) and GSH (green bars) in HDF cells treated with different concentrations of MUD1 $(250-750 \mu \mathrm{g} / \mathrm{mL})$ for $24 \mathrm{~h}$ or AAPH $(10 \mathrm{mM})$ for 24 $h$ and with different concentrations of MUD1 and then with AAPH. Data are expressed as mean values \pm SD. Columns with different superscript letters are significantly different $(p<0.05)$.

\subsection{MUD1 Treatment Improved the Endogenous Antioxidant Defence System}

Different studies indicated that honey and other natural bioactive compounds are able to modulate the activity of diverse antioxidant enzymes, reducing the damage induced by AAPH in HDF cells [11,21]. Under physiological conditions, the balance between prooxidant and antioxidant compounds moderately favors prooxidants, thus inducing a slight oxidative stress, requiring the intervention of endogenous antioxidant systems of the organism [22]. Redox homeostasis of the cell is assured by its complex endogenous antioxidant defense system, which includes endogenous antioxidant enzymes such as superoxide dismutase (SOD), catalase, glutathione peroxidase (GPx), non-enzymatic compounds and low molecular weight scavengers, like uric acid, coenzyme Q, and lipoic acid [23]. The results obtained in our works are in line with these previous data: MUD1 treatment was able to increase the enzymatic activity of GPx, glutathione reductase (GR) and glutathione trasferase (GST) in different doses, obtaining a significant difference in respect to the control group at doses of $250 \mu \mathrm{g} / \mathrm{mL}$ for GR and GST $(p<0.05)$ and at $750 \mu \mathrm{g} / \mathrm{mL}$ for GPx $(p<0.05)$ (Figure 4a). Similar results were obtained for SOD and catalase (Figure $4 b$ ). In all the different enzymes, AAPH treatment determined a significant reduction $(p<0.05)$ of enzymatic activities, which were efficiently counteracted by MUD1 treatment in a dose-dependent manner (Figure 4). These results confirm the hypothesis that AAPH causes oxidative damage, decreasing antioxidant enzymes activities since the reservoir is depleted to counteract the damage. Otherwise MUD1 reduced the AAPH effect, improving the enzyme activities and decreasing the induced damage. 

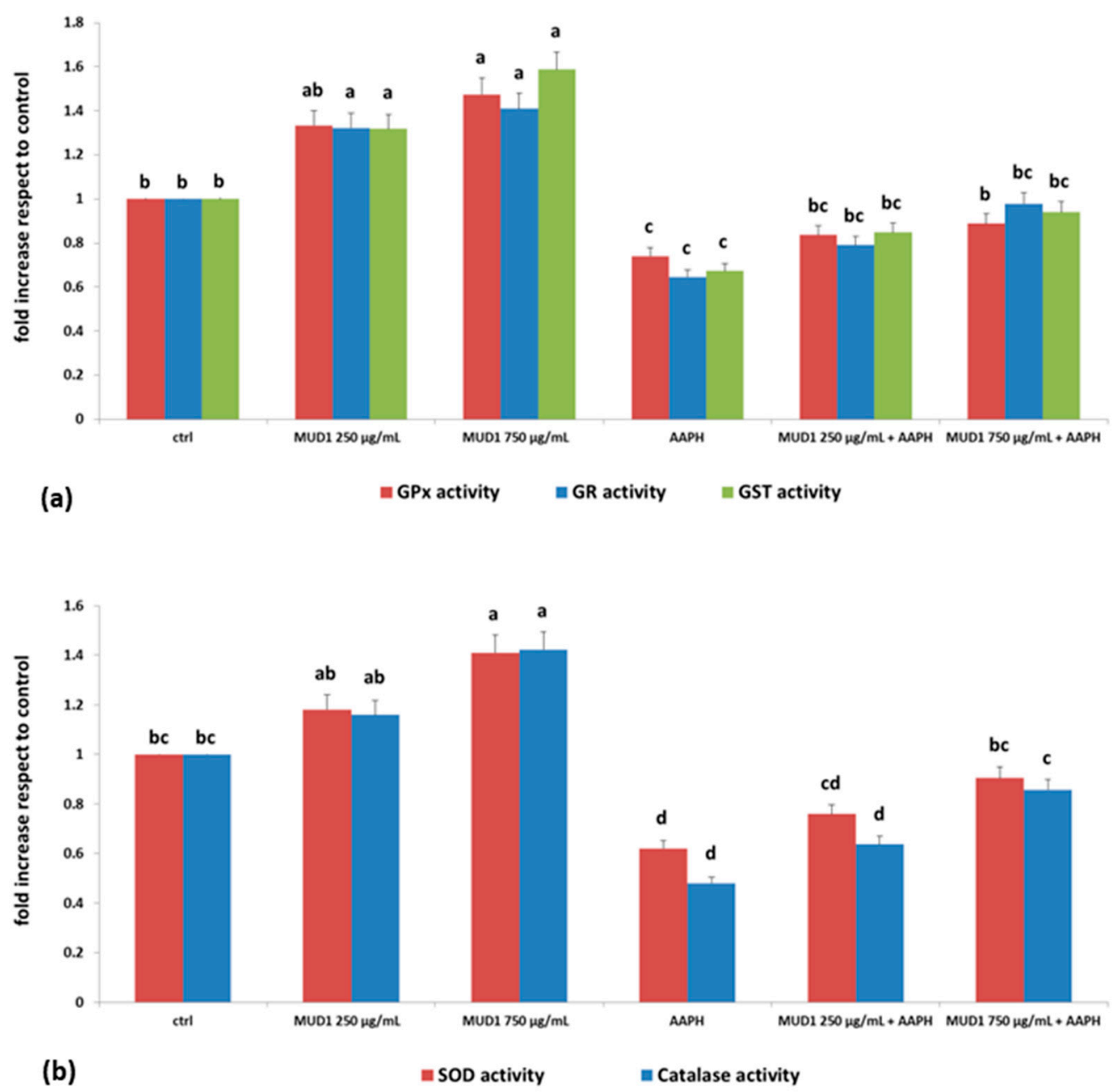

Figure 4. Glutathione peroxidase (GPX), glutathione reductase (GR), glutathione trasferase (GST) (a) and superoxide dismutase (SOD) and catalase (b) activities cell in HDF cells treated with different concentrations of MUD1 (250-750 $\mu \mathrm{g} / \mathrm{mL})$ for $24 \mathrm{~h}$ or AAPH $(10 \mathrm{mM})$ for $24 \mathrm{~h}$ and with different concentrations of MUD1 and then with AAPH. Data are expressed as mean values $\pm \mathrm{SD}$. Columns with different superscript letters are significantly different $(p<0.05)$.

\subsection{Effect of MUD1 Treatment on OCR and ECAR}

The electron transport chain in the mitochondria represents the most important site of ROS production [19]. According to the result found by ROS analysis, we evaluated the mitochondria dysfunction in HDF cells, by assessing oxidative phosphorylation and glycolysis: the first one acts as a major source of adenosine triphosphate (ATP) in almost all aerobic organisms, while glycolysis breaking down glucose produces pyruvate with two ATPs in the cytoplasm [24]. Figure 6a shows the oxygen consumption rate (OCR) trend of the different tested groups, in relation to the molecules applied: oligomycin, an inhibitor of ATP synthase, 2,4-Dinitrophenol (2,4 DNP), an uncoupling agent between the electron transport chain and oxidative phosphorylation, and antimycin A/rotenone, two common inhibitors of electron transport chain. Sequential injections of these compounds calculates basal respiration, maximal respiration, ATP production, proton leak, spare respiratory capacity, and non-mitochondrial respiration. Basal respiration is mainly regulated by the parallel re-entry pathways through the ATP synthase and proton leak. Oligomycin inhibits the ATP synthase and residual respiration is related to the proton leak. The addition of an appropriate concentration of the protonophore 2,4 DNP determines a high artificial proton conductance into the membrane. This maximal respiration is now owned by the electron transport chain activity and/or substrate delivery. 
The increased respiratory capacity above basal respiration represents the maximal respiratory capacity. In the end, inhibitors of the electron transport chain were injected: antimycin A/rotenone that block complex III and I, respectively. In this way, any residual respiration is non mitochondrial and needs to be removed from the other rates [25]. Starting from the baseline values of OCR, AAPH treatment strongly reduced the oxygen consumption in respect to the control group (Figure 5a). On the contrary, MUD1 treatment improved the mitochondrial respiration, increasing the OCR level in respect to the control and also neutralizing the depressive effect exerted by AAPH. The response to the inhibitor was the same for all the tested groups. Taking into account the maximal respiratory capacity (Figure $5 \mathrm{~b}$ ), MUD1 treatment efficiently improved this value: in particular, pre-treatment with MUD1 at $750 \mu \mathrm{g} / \mathrm{mL}$ before the AAPH incubation significantly contrasted the reduction of maximal respiratory capacity evoked by AAPH $(p<0.05)$. Since the maximal respiratory capacity indicates the maximum rate of respiration that cells can achieve in conditions of high energy demand, an augmentation of this parameter implies that cells are capable of rapidly oxidizing substrates (sugars, fats, amino acids) so that they can face this metabolic challenge. In previous studies our group has shown that other food matrices rich in antioxidant compounds are also capable of stimulating mitochondrial functionality in vitro [11,15] and in vivo [26].
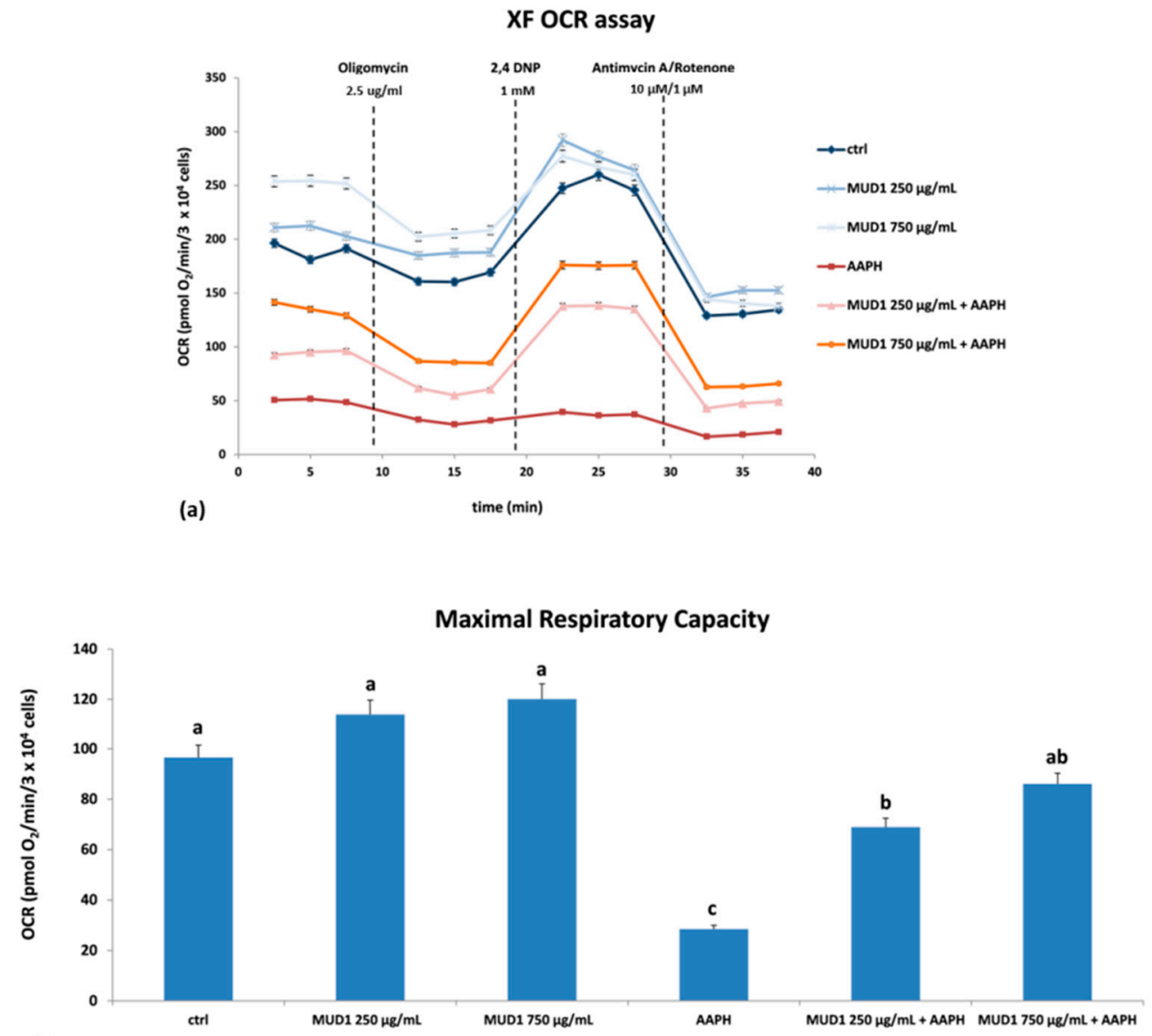

(b)

Figure 5. OCR (a) and maximal respiratory capacity (b) in HDF cells treated with different concentrations of MUD1 (250-750 $\mathrm{g} / \mathrm{mL})$ for $24 \mathrm{~h}$, AAPH $(10 \mathrm{mM})$ for $24 \mathrm{~h}$ and with different concentrations of MUD1 and then with AAPH. Data are expressed as mean values \pm SD. Columns belonging to the same set of data with different superscript letters are significantly different $(p<0.05)$.

With regard to the glycolytic pathway, starting from the baseline values of the extracellular acidification rate (ECAR), we observed that AAPH treatment remarkably increased the ECAR value, which was reduced through MUD1 treatment (Figure 6a). Furthermore, in this case different molecules 
were applied: rotenone, glucose, and 2-deoxyglucose (2-DG). As previously indicated rotenone blocks complex I, in this way any effect of mitochondria respiration was averted. The second injection was a saturating concentration of glucose. The cells utilize the glucose injection and catabolize it through the glycolytic pathway to pyruvate, producing ATP, NADH, water, and protons. The extrusion of protons into the surrounding medium causes a rapid increase in ECAR. The final injection was 2-DG, a glucose analog, that inhibits glycolysis through competitive binding to the first enzyme in the glycolytic pathway, glucose hexokinase. The resulting decrease in ECAR confirms that the ECAR produced in the experiment is due to glycolysis, and the difference between ECAR value after glucose injection and the final 2-DG value represent the maximal respiratory capacity [27]. As shown in Figure $6 a$, the response to the inhibitor was the same for all the tested groups. Finally, looking at the glycolytic capacity (Figure 6b), MUD1 treatment reduced this value significantly at $750 \mu \mathrm{g} / \mathrm{mL}$ $(p<0.05)$. AAPH treatment efficiently raised the value $(p<0.05)$, which was lowered after MUD1 pre-treatment at $750 \mu \mathrm{g} / \mathrm{mL}(p<0.05)$. Our results are in agreement with other published data that showed a significant decrease in ECAR values in lipopolysaccharide (LPS)-treated RAW macrophages after Manuka honey treatment in a dose-dependent way [28], as well as in LPS-treated HDF cells after polyphenol-rich fruits treatment [8].

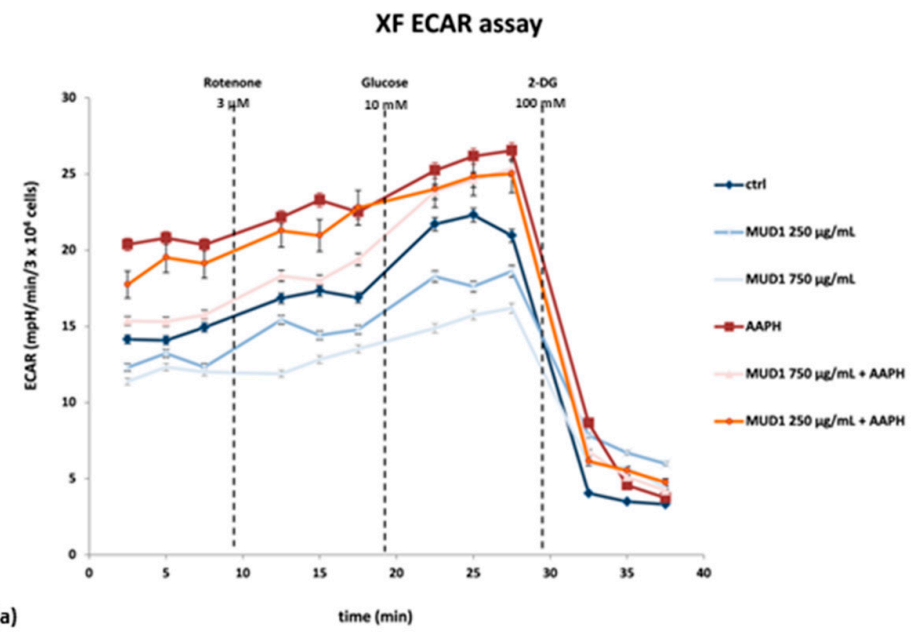

Glycolytic Capacity

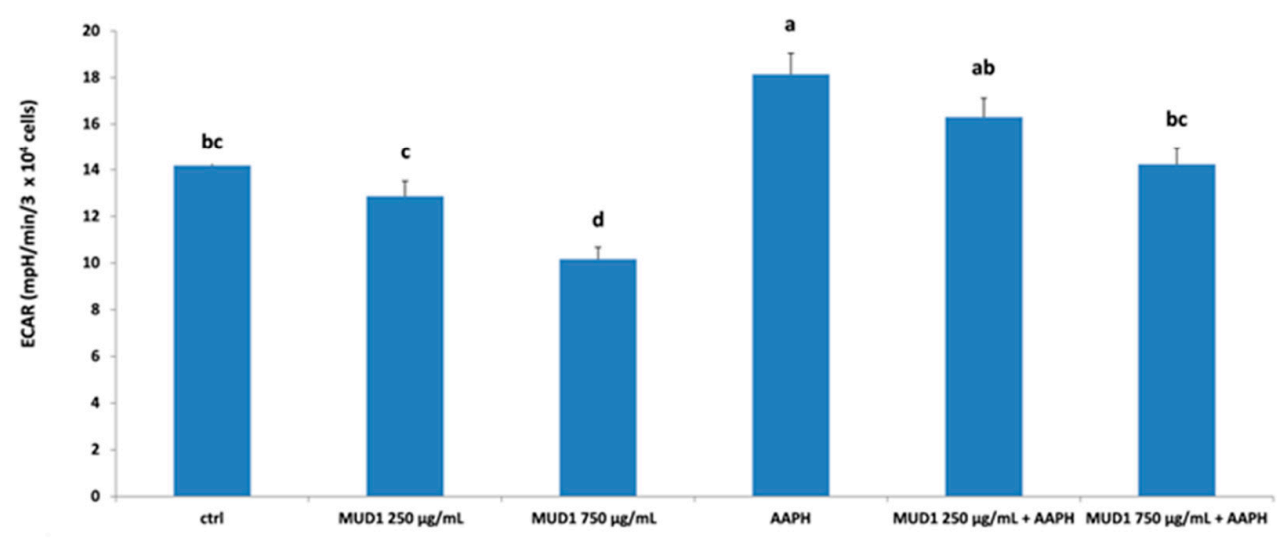

(b)

Figure 6. Extracellular acidification rate (ECAR) (a) and glycolytic capacity (b) in HDF cells treated with different concentrations of MUD1 (250-750 $\mu \mathrm{g} / \mathrm{mL})$ for $24 \mathrm{~h}$, AAPH $(10 \mathrm{mM})$ for $24 \mathrm{~h}$ and with different concentrations of MUD1 and then with AAPH. Data are expressed as mean values \pm SD. Columns belonging to the same set of data with different superscript letters are significantly different $(p<0.05)$. 


\subsection{MUD1 Promotes Tissue Repair by Fibroblast Migration and Wound Closure}

Numerous studies have highlighted the capacity of honey in healing chronic wounds in humans and animals [28-31]. This property can be related to the antibacterial capacity of honey and other mechanisms related to its physical properties, such as $\mathrm{pH}$, and to its immunostimulatory and anti-inflammatory effects [32,33]. Recent studies investigated the properties of honey, in repairing tissue through nitric oxide production, promoting migration, and enhancing wound closure in HDF cells treated with AAPH [11]. On the contrary, in the colon cancer cell model, honey exerted its positive effects reducing cell migration and invasion [27]. The wound scratch assay is a simple, economical, and highly sensitive method to determine cell migration in vitro; it is particularly useful for examining the effects of cell to cell connection and cell to matrix interactions, as well as imitate cell movement during wound healing in vivo.

In the present work a pre-treatment with MUD1 for $24 \mathrm{~h}$ slightly promoted scratch wound closure when compared to the control group, at both concentrations (Figure 7a,b). Treatment with AAPH significantly affected $(p<0.05)$ the migration of HDF and wound closure activity, while MUD1 pre-treatment was able to reduce this negative effect, restoring values similar to the control at $750 \mu \mathrm{g} / \mathrm{mL}$. These results confirm that MUD1 promotes tissue repair by favoring cell migration and it could be used in the topical treatment of wounds, although future in vivo studies would be necessary.

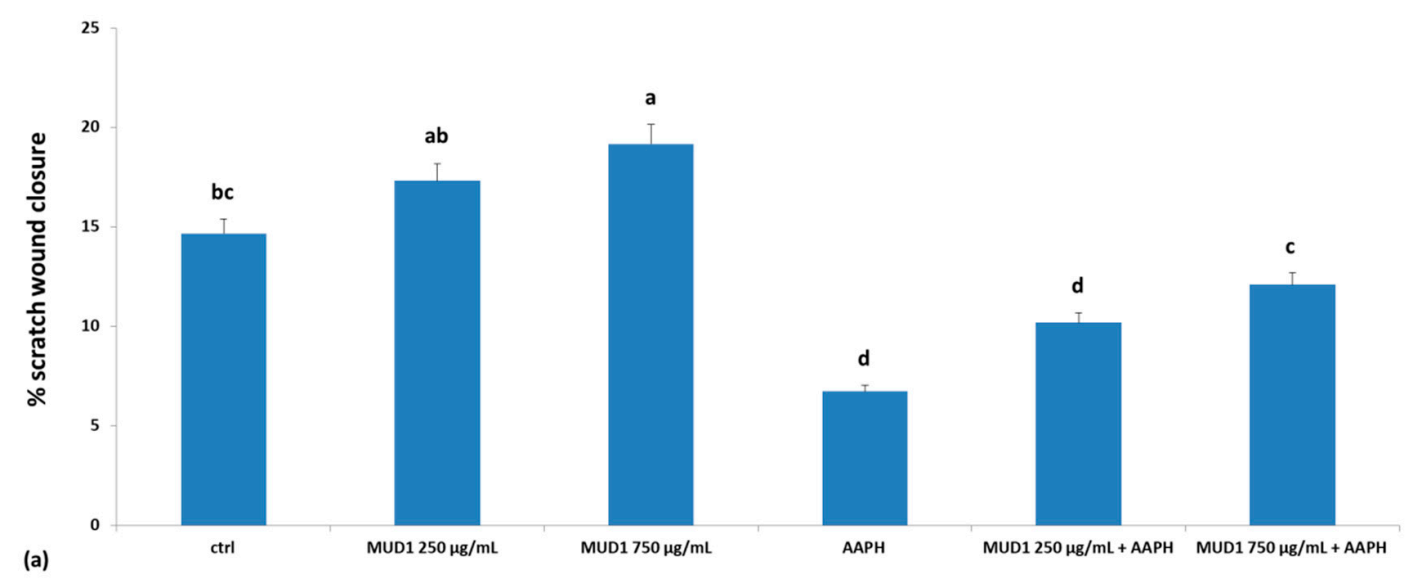

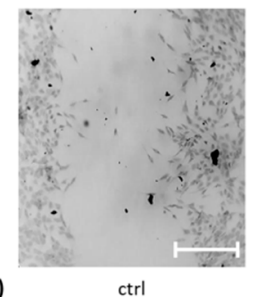

(b)

ctrl

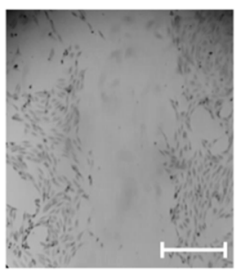

MUD1 $250 \mu \mathrm{g} / \mathrm{mL}$

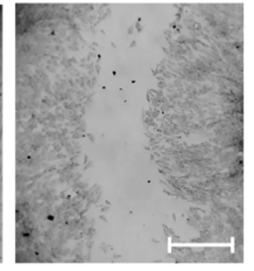

MUD1 $750 \mu \mathrm{g} / \mathrm{mL}$

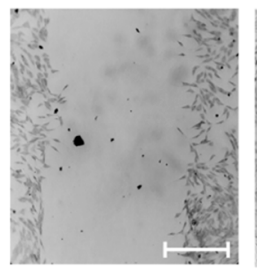

AAPH

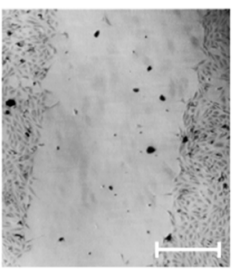

MUD1 $250 \mu \mathrm{g} / \mathrm{mL}+$ AAPH

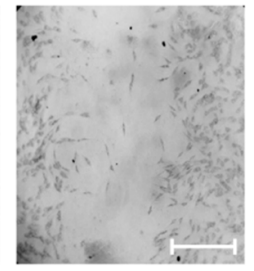

MUD1 $750 \mu \mathrm{g} / \mathrm{mL}+\mathrm{AAPH}$

Figure 7. Scratch wound closure (a) in HDF cells treated with different concentrations of MUD1 $(250-750 \mu \mathrm{g} / \mathrm{mL})$ for $24 \mathrm{~h}$ or AAPH $(10 \mathrm{mM})$ for $24 \mathrm{~h}$ and with different concentrations of MUD1 and then with AAPH. Data are expressed as mean values \pm SD. Columns with different superscript letters are significantly different $(p<0.05)$. Representative images illustrating the migration of HDF cells into the scratch wound during different treatments exposure $(\mathbf{b})$. Scale bars $=100 \mu \mathrm{m}$

\section{Materials and Methods}

All chemicals and reagents were bought from Sigmae-Aldrich Chemical Company (Sigma-Aldrich, St. Luis, MO, USA). 


\subsection{Sample Collection and Preparation}

The combs were collected and subjected to a heating process by steam during the recycling process of the wax honeycombs. A fraction with organic and inorganic waste was isolated from wax (MUD1), which included pollen, molting debris of baby bees, etc. Five samples of MUD1 were randomly harvested from total MUDs and subjected to hydrophilic extraction, as previously reported [34] by diluting $1 \mathrm{~g}$ of MUD1 in $10 \mathrm{~mL}$ of distilled water and filtered through Minisart filter of $45 \mu \mathrm{m}$ (PBI TInternational).

\subsection{Cell Culture and Treatments}

Adult skin HDF were obtained by GIBCO $^{\circledR}$ Invitrogen cell (Waltham, MA, USA), plated into a T-75 flasks and cultured as previously reported [7]. Cells were treated with (i) Dulbecco's Modified Eagle Medium (DMEM) only (ctrl group); (ii) MUD1 hydrophilic extract for $24 \mathrm{~h}$ at 250 and $750 \mu \mathrm{g} / \mathrm{mL}$; (iii) AAPH for $24 \mathrm{~h}$ at $10 \mathrm{mM}$; (iv) MUD1 for $24 \mathrm{~h}$ at 250 and $750 \mu \mathrm{g} /$, and then with AAPH $10 \mathrm{mM}$ for $24 \mathrm{~h}$. The combination of dose/time MUD1 treatments was chosen according to our preliminary cytotoxic study. The dose/time treatment of AAPH was chosen according to our previous studies [11].

\subsection{TALI ${ }^{\circledR}$ ROS Concentration Assay}

The ROS intracellular levels determination was performed using the CellROX ${ }^{\circledR}$ Orange reagent (Invitrogen, Life Technologies, Milan, Italy) according to the manufacturer's instructions, as previously reported by our group [24]. Each treatment was performed in three replicates and the final results were reported as a fold increase compared to the control.

\subsection{Determination of Nitrite Production}

$\mathrm{NO}_{2}{ }^{-}$in cell culture media was determined by the Griess method [35]. Each treatment was carried out in three replicates and the final results were expressed as a fold increase in respect to the control.

\subsection{Apoptosis Detection}

Apoptosis was assessed by the Tali ${ }^{\mathrm{TM}}$ apoptosis assay kit (Invitrogen ${ }^{\mathrm{TM}}$, Life Technologies, Monza, Italy), which uses Annexin V Alexa Fluor ${ }^{\mathrm{TM}} 488$ (Invitrogen ${ }^{\mathrm{TM}}$, Life Technologies, Monza, Italy) and propidium iodide (Invitrogen ${ }^{\mathrm{TM}}$, Life Technologies, Monza, Italy) to differentiate cells as live, dead, or apoptotic as previously indicated [24]. Each treatment was performed in three replicates and the final results were reported as a fold increase compared to the control.

\subsection{Measurements of the Protein and Lipid Oxidative Damage}

For the measurement of protein and lipid oxidative damage, each HDF was treated as previously reported [36-39]. Each sample was analyzed in three replicates and the final results were expressed as a fold increase in respect to the control.

\subsection{Antioxidant Enzyme Activities}

HDF cells were incubated with a RIPA buffer on ice for $5 \mathrm{~min}$ and the lysate analyzed for the antioxidant enzyme activities of GPx, GR, GST, SOD, and catalase as previously reported by Giampieri et al. [40]. Each treatment was carried out in three replicates and the final results were expressed as a fold increase in respect to the control.

\subsection{Determination of Mitochondrial Respiration and Extracellular Acidification Rate in Cells}

XF-24 Extracellular Flux Analyzer was employed to evaluate in real-time OCR and ECAR, as previously indicated $[8,25]$. 


\subsection{In Vitro Skin Fibroblast Migration and Proliferation Assay}

HDF cells were seeded into 12-well plate and assessed as previously reported [11,41]. The experiments were made in triplicate and five representative images were made for each wound at randomly chosen points.

\subsection{Statistical Analysis}

STATISTICA software (Statsoft Inc., Tulsa, OK, USA) were used to perform the statistical analysis. Data were subjected to one-way ANOVA analysis of variance for mean comparison, and significant differences among different treatments were calculated according to HSD Tukey's multiple range test. Data are reported as mean $\pm \mathrm{SD}$. Differences at $p<0.05$ were considered statistically significant.

\section{Conclusions}

The research of a new life for by-products, before they become waste, is the new goal of the food processing industry. In this study we confirmed and underlined the important antioxidant effects of beeswax by-products, which are mainly related to their phenolic contents, and in particular to flavonoids, as we have previously reported [2]. It is widely accepted that these compounds are able to exert many healthy effects, and the antioxidant capacity is one of the most well-known and studied properties in different experimental models; reported for quercetin and its glycosides, raw honey on $\mathrm{Cu}^{2+}$-induced oxidative stress in HepG2 cells [42,43], LPS-stimulated RAW 264.7 cells [44,45], strawberry anthocyanins on AAPH-, and LPS-induced stress on human dermal fibroblasts $[8,21]$. In the present work, we showed for the first time the protective effect of beeswax by-products against oxidative damage induced by AAPH in HDF cells. An improvement of oxidative status and antioxidant defenses was detected; simultaneously an enhancement of mitochondria functionality and wound healing properties were also marked. The results obtained can represent an interesting starting point for the development of new functional foods based on beeswax by-products. Future studies that investigate the molecular mechanisms involved in these antioxidant properties must be performed, both through in vitro and in vivo models.

Author Contributions: M.G., S.A. and T.Y.F.-H. conceived and designed the experiments under the supervision of M.B., S.B. and F.G. M.G., P.P.M., J.Z., P.R.-R. and D.C. performed the experiments. J.L.Q., C.T.F.-P. and F.J.O.-B. provided beeswax by-products. M.G. and F.G. wrote the paper. All of the authors made essential contributions to the manuscript revision and approved the final version of the text.

Acknowledgments: The present study was partially funded by the "National Beekeeping Aid Program (Programa Nacional de Ayudas a la Apicultura)", cofounded by the European Union and assigned to Spanish FEGA and FEAGA agencies. Patricia Reboredo-Rodríguez acknowledges award of a post-doctoral contract from Xunta de Galicia.

Conflicts of Interest: The authors declare no conflict of interest

\section{Abbreviations}

$\begin{array}{ll}\text { 2,4 DNP } & \text { 2,4-Dinitrophenol } \\ \text { 2-DG } & \text { 2-deoxyglucose } \\ \text { AAPH } & \text { 2,2'-azobis(2-amidinopropane) dihydrochloride } \\ \text { ABB } & \text { annexin binding buffer } \\ \text { DMEM } & \text { Dulbecco's Modified Eagle Medium } \\ \text { ECAR } & \text { extracellular acidification rate } \\ \text { HDF } & \text { human dermal fibroblast } \\ \text { HepG2 } & \text { human hepatocellular carcinoma } \\ \text { GPx } & \text { glutathione peroxidase } \\ \text { GR } & \text { glutathione reductase } \\ \text { GSH } & \text { glutathione } \\ \text { GST } & \text { glutathione trasferase }\end{array}$




$\begin{array}{ll}\mathrm{NO} & \text { nitric oxide } \\ \mathrm{NO}_{2}{ }^{-} & \text {nitrite } \\ \mathrm{OCR} & \text { oxygen consumption rate } \\ \text { PBS } & \text { phosphate-buffered saline solution } \\ \text { ROS } & \text { reactive oxygen species } \\ \text { SOD } & \text { superoxide dismutase } \\ \text { TBARS } & \text { thiobarbituric acid-reactive substances }\end{array}$

\section{References}

1. Baiano, A. Recovery of biomolecules from food wastes-A review. Molecules 2014, 19, 14821-14842. [CrossRef] [PubMed]

2. Giampieri, F.; Quiles, J.L.; Orantes-Bermejo, F.J.; Gasparrini, M.; Forbes-Hernandez, T.Y.; Sánchez-González, C.; Llopis, J.; Rivas-García, L.; Afrin, S.; Varela-López, A.; et al. Are by-products from beeswax recycling process a new promising source of bioactive compounds with biomedical properties? Food Chem. Toxicol. 2018, 112, 126-133. [CrossRef] [PubMed]

3. Crowder, L. Top-Bar Beekeeping: Organic Practices for Honeybee Health; Chelsea Green Publishing: White River Junction, VT, USA, 2012; ISBN 1603584617.

4. Fratini, F.; Cili, G.; Turchi, B.; Felicioli, A. Beeswax: A minireview of its antimicrobial activity and its application in medicine. Asian Pac. J. Trop. Med. 2016, 9, 839-843. [CrossRef] [PubMed]

5. Scientific Opinion of the Panel on Food additives, Flavourings, Processing aids and Materials in Contact with Food (AFC) on a request from the Commission on the safety in use of beeswax. EFSA J. 2007, 615, 1-28.

6. Mayne, S.T. Antioxidant nutrients and chronic disease: Use of biomarkers of exposure and oxidative stress status in epidemiologic research. J. Nutr. 2003, 133, S933-S940. [CrossRef] [PubMed]

7. Gasparrini, M.; Forbes-Hernandez, T.Y.; Giampieri, F.; Afrin, S.; Mezzetti, B.; Quiles, J.L.; Bompadre, S.; Battino, M. Protective Effect of Strawberry Extract against Inflammatory Stress Induced in Human Dermal Fibroblasts. Molecules 2017, 22, 164. [CrossRef] [PubMed]

8. Gasparrini, M.; Giampieri, F.; Forbes-Hernandez, T.Y.; Afrin, S.; Cianciosi, D.; Reboredo-Rodriguez, P.; Varela-Lopez, A.; Zhang, J.; Quiles, J.L.; Mezzetti, B.; et al. Strawberry extracts efficiently counteract inflammatory stress induced by the endotoxin lipopolysaccharide in Human Dermal Fibroblast. Food Chem. Toxicol. 2018, 114, 128-140. [CrossRef] [PubMed]

9. Pistollato, F.; Battino, M. Role of plant-based diets in the prevention and regression of metabolic syndrome and neurodegenerative diseases. Trends Food Sci. Technol. 2014, 40, 62-81. [CrossRef]

10. Afrin, S.; Forbes-Hernandez, T.Y.; Gasparrini, M.; Bompadre, S.; Quiles, J.L.; Sanna, G.; Spano, N.; Giampieri, F.; Battino, M. Strawberry-tree honey induces growth inhibition of human colon cancer cells and increases ROS generation: A comparison with Manuka honey. Int. J. Mol. Sci. 2017, 18, 613. [CrossRef] [PubMed]

11. Alvarez-Suarez, J.M.; Giampieri, F.; Cordero, M.; Gasparrini, M.; Forbes-Hernandez, T.Y.; Mazzoni, L.; Afrin, S.; Beltran-Ayala, P.; Gonzalez-Paramas, A.M.; Santos-Buelga, C.; et al. Activation of AMPK/Nrf2 signalling by Manuka honey protects human dermal fibroblasts against oxidative damage by improving antioxidant response and mitochondrial function promoting wound healing. J. Funct. Foods 2016, 25, 38-49. [CrossRef]

12. Schieber, M.; Chandel, N.S. ROS function in redox signaling and oxidative stress. Curr. Biol. 2014, 24, 453-462. [CrossRef] [PubMed]

13. Wang, R.; Ghahary, A.; Shen, Y.J.; Scott, P.G.; Tredget, E.E. Human dermal fibroblasts produce nitric oxide and express both constitutive and inducible nitric oxide synthase isoforms. J. Investig. Dermatol. 1996, 106, 419-427. [CrossRef] [PubMed]

14. Park, C.M.; Park, J.Y.; Noh, K.H.; Shin, J.H.; Song, Y.S. Taraxacum officinale Weber extracts inhibit LPS-induced oxidative stress and nitric oxide production via the NF-kB modulation in RAW264.7 cells. J. Ethnopharmacol. 2011, 133, 834-842. [CrossRef] [PubMed]

15. Giampieri, F.; Alvarez-Suarez, J.M.; Mazzoni, L.; Forbes-Hernandez, T.Y.; Gasparrini, M.; González-Paramás, A.M.; Santos-Buelga, C.; Quiles, J.L.; Bompadre, S.; Mezzetti, B.; et al. Polyphenol-Rich Strawberry Extract Protects Human Dermal Fibroblasts against Hydrogen Peroxide Oxidative Damage and Improves Mitochondrial Functionality. Molecules 2014, 19, 7798-7816. [CrossRef] [PubMed] 
16. Gasparrini, M.; Forbes-Hernandez, T.Y.; Afrin, S.; Reboredo-Rodríguez, P.; Cianciosi, D.; Mezzetti, B.; Quiles, J.L.; Bompadre, S.; Battino, M.; Giampieri, F. Strawberry-Based Cosmetic Formulations Protect Human Dermal Fibroblasts against UVA-Induced. Nutrients 2017, 9, 605. [CrossRef] [PubMed]

17. Forbes-Hernández, T.Y.; Giampieri, F.; Gasparrini, M.; Mazzoni, L.; Quiles, J.L.; Alvarez-Suarez, J.M.; Battino, M. The effects of bioactive compounds from plant foodson mitochondrial function: A focus on apoptotic mechanisms. Food Chem. Toxicol. 2014, 68, 154-182. [CrossRef] [PubMed]

18. Babujanarthanam, R.; Kavitha, P.; Mahadeva Rao, U.S.; Pandian, M.R. Quercitrin a bioflavonoid improves the antioxidant status in streptozotocin: Induced diabetic rat tissues. Mol. Cell. Biochem. 2011, 358, 121-129. [CrossRef] [PubMed]

19. Dalle-Donne, I.; Rossi, R.; Giustarini, D.; Milzani, A.; Colombo, R. Protein carbonyl groups as biomarkers of oxidative stress. Clin. Chim. Acta 2003, 329, 23-38. [CrossRef]

20. DeLeve, L.D.; Kaplowitz, N. Importance and regulation of hepatic glutathione. Semin. Liver Dis. 1990, 10, 251-266. [CrossRef] [PubMed]

21. Giampieri, F.; Alvarez-Suarez, J.M.; Mazzoni, L.; Forbes-Hernandez, T.Y.; Gasparrini, M.; Gonzàlez-Paramàs, A.M.; Santos-Buelga, C.; Quiles, J.L.; Bompadre, S.; Mezzetti, B.; et al. An anthocyanin-rich strawberry extract protects against oxidative stress damage and improves mitochondrial functionality in human dermal fibroblasts exposed to an oxidizing agent. Food Funct. 2014, 5, 1939-1948. [CrossRef] [PubMed]

22. Dröge, W. Free radicals in the physiological control of cell function. Physiol. Rev. 2002, 82, 47-95. [CrossRef] [PubMed]

23. Poljsak, B.; Šuput, D.; Milisav, I. Achieving the balance between ROS and antioxidants: When to use the synthetic antioxidants. Oxid. Med. Cell Longev. 2013, 2013, 956792. [CrossRef] [PubMed]

24. Islam, M.S.; Giampieri, F.; Janjusevic, M.; Gasparrini, M.; Forbes-Hernandez, T.Y.; Mazzoni, L.; Greco, S.; Giannubilo, S.R.; Ciavattini, A.; Mezzetti, B.; et al. An anthocyanin rich strawberry extract induces apoptosis and ROS while decreases glycolysis and fibrosis in human uterine leiomyoma cells. Oncotarget 2017, 8, 23575-23587. [CrossRef] [PubMed]

25. Gasparrini, M.; Forbes-Hernandez, T.Y.; Giampieri, F.; Afrin, S.; Alvarez-Suarez, J.M.; Mazzoni, L.; Mezzetti, B.; Quiles, J.L.; Battino, M. Anti-inflammatory effect of strawberry extract against LPS-induced stress in RAW 264.7 macrophages. Food Chem. Toxicol. 2017, 102, 1-10. [CrossRef] [PubMed]

26. Giampieri, F.; Alvarez-Suarez, J.M.; Cordero, M.D.; Gasparrini, M.; Forbes-Hernandez, T.Y.; Afrin, S.; Santos-Buelga, C.; González-Paramás, A.M.; Astolfi, P.; Rubini, C.; et al. Strawberry consumption improves aging-associated impairments, mitochondrial biogenesis and functionality through the AMP-activated protein kinase signaling cascade. Food Chem. 2017, 234, 464-471. [CrossRef] [PubMed]

27. Afrin, S.; Giampieri, F.; Gasparrini, M.; Forbes-Hernández, T.Y.; Cianciosi, D.; Reboredo-Rodriguez, P.; Manna, P.P.; Zhang, J.; Quiles, J.L.; Battino, M. The inhibitory effect of Manuka honey on human colon cancer HCT-116 and LoVo cell growth. Part 2: Induction of oxidative stress, alteration of mitochondrial respiration and glycolysis, and suppression of metastatic ability. Food Funct. 2018, 9, 2158-2170. [CrossRef] [PubMed]

28. Afrin, S.; Gasparrini, M.; Forbes-Hernández, T.Y.; Cianciosi, D.; Reboredo-Rodriguez, P.; Manna, P.P.; Battino, M.; Giampieri, F. Protective effects of Manuka honey on LPS-treated RAW 264.7 macrophages. Part 1: Enhancement of cellular viability, regulation of cellular apoptosis and improvement of mitochondrial functionality. Food Chem. Toxicol. 2018, 121, 203-213. [CrossRef] [PubMed]

29. Bischofberger, A.S.; Tsang, A.S.; Horadagoda, N.; Dart, C.M.; Perkins, N.R.; Jeffcott, L.B.; Jackson, C.J.; Dart, A.J. Effect of activated protein $C$ in second intention healing of equine distal limb wounds: A preliminary study. Aust. Vet. J. 2015, 93, 361-366. [CrossRef] [PubMed]

30. Bischofberger, A.S.; Dart, C.M.; Horadagoda, N.; Perkins, N.R.; Jeffcott, L.B.; Little, C.B.; Dart, A.J. Effect of Manuka honey gel on the transforming growth factor $\beta 1$ and $\beta 3$ concentrations, bacterial counts and histomorphology of contaminated full-thickness skin wounds in equine distal limbs. Aust. Vet. J. 2016, 94, 27-34. [CrossRef] [PubMed]

31. Sell, S.A.; Wolfe, P.S.; Spence, A.J.; Rodriguez, I.A.; McCool, J.M.; Petrella, R.L.; Garg, K.; Ericksen, J.J.; Bowlin, G.L. A preliminary study on the potential of manuka honey and platelet-rich plasma in wound healing. Int. J. Biomater. 2012, 2012, 313781. [CrossRef] [PubMed]

32. Molan, P.C. The evidence and the rationale for the use of honey as a wound dressing. Wound Pract. Res. 2011, 19, 204-220.

33. Molan, P.; Rhodes, T. Honey: A biologic wound dressing. Wounds 2015, 27, 141-151. [PubMed] 
34. Alvarez-Suarez, J.M.; Tulipani, S.; Díaz, D.; Estevez, Y.; Romandini, S.; Giampieri, F.; Damiani, E.; Astolfi, P.; Bompadre, S.; Battino, M. Antioxidant and antimicrobial capacity of several monofloral Cuban honeys and their correlation with color, polyphenol content and other chemical compounds. Food Chem. Toxicol. 2010, 48, 2490-2499. [CrossRef] [PubMed]

35. Pekarova, M.; Kralova, J.; Kubala, L.; Ciz, M.; Papezikova, I.; Macickova, T.; Pecivova, J.; Nosal, R.; Lojek, A. Carvedilol and adrenergic agonists suppress the lipopolysaccharide-induced NO production in RAW 264.7 macrophages via the adrenergic receptors. J. Physiol. Pharmacol. 2009, 60, 143-150. [PubMed]

36. Doktorovová, S.; Santos, D.L.; Costa, I.; Andreani, T.; Souto, E.B.; Silva, A.M. Cationic solid lipid nanoparticles interfere with the activity of antioxidant enzymes in hepatocellular carcinoma cells. Int. J. Pharm. 2014, 471, 18-27. [CrossRef] [PubMed]

37. Levine, R.L.; Garland, D.; Oliver, C.N.; Amici, A.; Climent, I.; Lenz, A.G.; Ahn, B.W.; Shaltiel, S.; Stadtman, E.R. Determination of carbonyl content in oxidatively modified proteins. Methods Enzymol. 1990, 186, 464-478. [CrossRef] [PubMed]

38. Griffith, O.W. Determination of glutathione and glutathione disulfide using glutathione reductase and 2-vinylpyridine. Anal. Biochem. 1980, 106, 207-212. [CrossRef]

39. Ohkawa, H.; Ohishi, N.; Yagi, K. Assay for lipid peroxides in animal tissues by thiobarbituric acid reaction. Anal. Biochem. 1979, 95, 351-358. [CrossRef]

40. Giampieri, F.; Alvarez-Suarez, J.M.; Gasparrini, M.; Forbes-Hernandez, T.Y.; Afrin, S.; Bompadre, S.; Rubini, C.; Zizzi, A.; Astolfi, P.; Santos-Buelga, C.; et al. Strawberry consumption alleviates doxorubicin-induced toxicity by suppressing oxidative stress. Food Chem. Toxicol. 2016, 94, 128-137. [CrossRef] [PubMed]

41. Esposito, D.; Munafo, J.P., Jr.; Lucibello, T.; Baldeon, M.; Komarnytsky, S.; Gianfagna, T.J. Steroidal glycosides from the bulbs of Easter lily (Lilium longiflorum Thunb.) promote dermal fibroblast migration in vitro. J. Ethnopharmacol. 2013, 148, 433-440. [CrossRef] [PubMed]

42. Kim, G.N.; Kwon, Y.; Jang, H.D. Protective mechanism of quercetin and rutin on 2,2'-azobis(2-amidinopropane)dihydrochloride or $\mathrm{Cu}^{2+}$-induced oxidative stress in HepG2 cells. Toxicol. In Vitro 2011, 25, 138-144. [CrossRef] [PubMed]

43. Kim, G.N.; Jang, H.D. Flavonol content in the water extract of the mulberry (Morus alba L.) leaf and their antioxidant capacities. J. Food Sci. 2011, 76, C869-C873. [CrossRef] [PubMed]

44. Choi, S.J.; Tai, B.H.; Cuong, N.M.; Kim, Y.-K.; Jang, H.D. Antioxidative and anti-inflammatory effect of quercetin and its glycosides isolated from mampat (Cratoxylum formosum). Food Sci. Biotechnol. 2012, $21,587$. [CrossRef]

45. Gasparrini, M.; Afrin, S.; Forbes-Hernández, T.Y.; Cianciosi, D.; Reboredo-Rodriguez, P.; Amici, A.; Battino, M.; Giampieri, F. Protective effects of Manuka honey on LPS-treated RAW 264.7 macrophages. Part 2: Control of oxidative stress induced damage, increase of antioxidant enzyme activities and attenuation of inflammation. Food Chem. Toxicol. 2018, 120, 578-587. [CrossRef] [PubMed]

(C) 2018 by the authors. Licensee MDPI, Basel, Switzerland. This article is an open access article distributed under the terms and conditions of the Creative Commons Attribution (CC BY) license (http://creativecommons.org/licenses/by/4.0/). 